\title{
Article \\ One or several Jews? The Jewish massed body in Old Norse literature
}

\author{
Richard Cole \\ Program in Scandinavian Studies, Harvard University, Cambridge, MA.
}

\begin{abstract}
In this article, I seek to articulate a troubling quality in Old Norse depictions of the Jewish body: namely, its contiguity, inscrutability and lack of individuality. In Old Norse literature (visual culture is a different matter) the usual somatic markers of medieval antisemitism, such as hooked noses, dark skin and effeminacy, are conspicuous by their absence. Rather, Jews are often rendered 'Other' by the organization of their bodies. Like a sort of hive-mind, they appear to act as one, speak as one, and plot, scheme and rage as one. Drawing on Deleuze and Guattari's thoughts on multiplicity, I propose culturally specific implications of these images for medieval Icelandic society. Jews are also contextualized among the tropes surrounding other non-Christians in Old Norse, namely, pagans and Muslims, with a particular emphasis on the figure of the blámaðr (lit. 'black man').
\end{abstract}

postmedieval: a journal of medieval cultural studies (2014) 5, 346-358.

doi:10.1057/pmed.2014.18

Fanny is listening to a program on wolves. I say to her, Would you like to be a wolf? She answers haughtily, How stupid, you can't be one wolf. You're always eight or nine, six or seven. Not six or seven wolves all by yourself all at once, but one wolf among others, with five or six others.

Deleuze and Guattari, A Thousand Plateaus:

Capitalism and Schizophrenia 
In the first chapter of A Thousand Plateaus, '1914: One or Several Wolves?', Deleuze is already at work reclaiming as heroes those he perceives as the original victims of Freudian psychoanalysis. In his hands, the once neurotic Wolf-Man becomes a schizo; his condition is no illness, but an articulation of the fear and self-denial of everything in society that is repressive, fascist, and 'Oedipal.' For Deleuze, the Wolf-Man's dreams are the site of a deep concern over multiplicity. The pack, though it may be understood as a cipher for a number of Deleuzo-Guattarian neologisms, is always a challenge to static selfhood. It snaps at the heels of the fallacious concept of a free-floating subject, independent of the objects it observes. The weird plurality of the pack queries who is who, who owns which space, what is indivisible and what is individual (Figure 1).

This is why an essay about Old Norse literature begins with a conversation between a French poststructuralist philosopher and his wife. When Fanny tells Deleuze of the impossibility of being 'one wolf,' she describes a problem that has much in common with the one that inspires this study - a problem that has lacked substantial description. Why is it so rare to see only 'one Jew' in Old Norse texts? Medievalists are accustomed to understanding Judeo-Christian relations via a solitary, almost monumental, figure in the form of 'the something Jew' - for example, 'the hermeneutical Jew' (Cohen, 1999), 'the virtual Jew' (Tomasch, 2000) and 'the spectral Jew' (Kruger, 2005). But what is the significance of the fact that, outside the philo-Semitic works of Bishop Brandr Jónsson (c. 12051264), ${ }^{1}$ there are comparatively few examples of a singular gyðingr or júði. Instead, the Norse homilies and miracula abound with plural gyðingar or júðar. Fanny's reproach is not necessarily the starting point of a rigidly DeleuzoGuattarian reading where key concepts are reductively mapped on to the fixtures

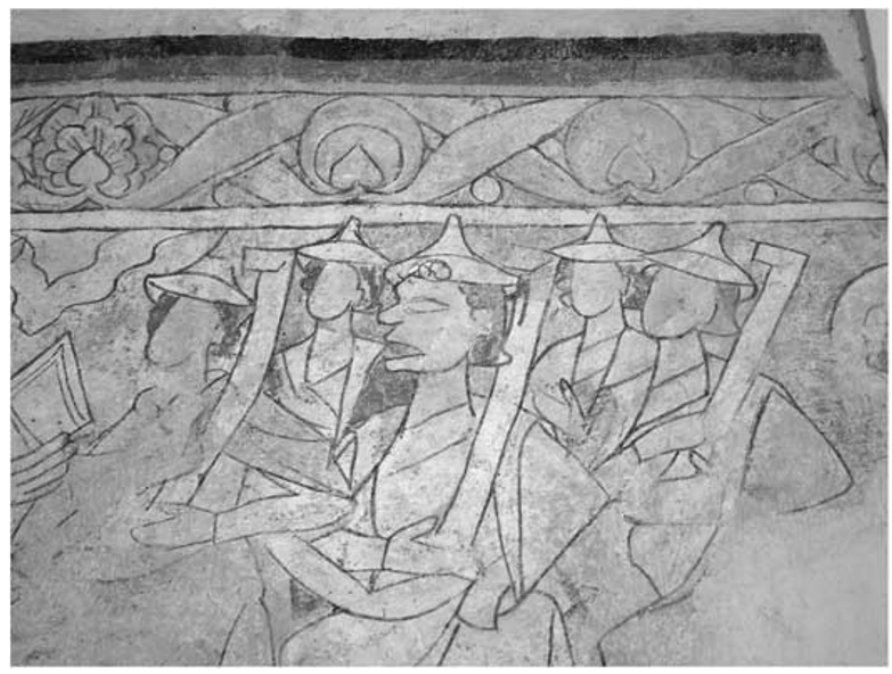

Figure 1: Chalk painting from Åhus church, then Denmark, now Sweden. c. 1275-1300. Source: www.kalkmalerier.dk
1 Specifically Gyðinga saga and possibly Konungs Skuggsjá (Kirby, 1986, 169-181).

These texts can to differing extents be characterized as histories of the Jews structured primarily around Biblical sources. Stjórn III was once widely attributed to Brandr, and would certainly fit this definition, although serious doubt has been cast on his involvement by Wolf (1990). 
2 For a list of the many attestations of the word, see Degnbol et al (1989), s.v. gyðinga•lýðr. Compared with gyðinga•lið, 'host of the Jews.'

3 Space does not allow for a discussion of the various Finnic heathens, who are more properly racial Others first, and religious Others second. For a fascinating study on this theme, see Straubhaar (2001). of Norse narratives. However, it should certainly prompt us to follow the general line of questioning which $\mathrm{Mr}$ and Mrs Deleuze recommend. What fears and taboos lie beneath or emanate from these multiplicities? What is it in the swarming of Freud's pack of wolves and a Norse homilist's gyðinga lý $\partial r$ (people of the Jews) that makes them so troubling? ${ }^{2}$

It is this tendency for the imagined Jews in Old Norse literature to appear and act as a group - indeed, as a kind of hateful chorus - that leads to their description here as a 'massed body.' Later, we will also briefly consider how far this concept of the Jews as a conglomerated corporeal entity extends to the antisemitic thinking that lay behind the Holocaust. A survey of medieval literature in general will reveal that the body has been a much-favored site for the antisemitic imagination. Here we can find bodies of Jews that are horned, tailed, malodorous, feminized or hideously corrupted with disease (Trachtenburg, 1943, 44-48; Rubin, 1999, 72-73; Kruger, 1992, 303). Neither can it be ignored that, as Kruger notes: 'Jewish bodies were often themselves seen as the appropriate targets of violence' (Kruger, 1992, 301-323). In Old Norse literature, however, we do not find any of these traditional aberrations appended to the Jewish body. Hooked noses rarely occur in manuscript illuminations (Björnsson, 1954, 57, 214), and Andersson has suggested that the 'crooked nose' (niðrbjúgt nef) of the turncoat Jarl Sigvaldi may be an allusion to the treachery of Judas, but these are very isolated cases (Andersson, 2003, 33). On the whole, it is not the way Jews look that renders them foreign. Rather, it is their curious ability to speak, act and seemingly think in perfect cohesion. If Krummel speaks of 'crafting' the absent Jew in medieval England (Krummel, 2011), perhaps we can only speak of 'moulding' the Jew in medieval Scandinavia, for there Jews are so often presented as a coagulated and contiguous mass. Like Deleuze's wolves, the gyðingar are worryingly, teemingly indivisible. They have no gender, odour, height or hue. We cannot locate the heads nor tails of a Jewish man or a Jewish woman. We cannot see where Jewish adult or child, priest or laity begins or ends. There is only the massed body, possessed of an inscrutable physicality to match its inscrutable unified consciousness.

As might be expected from one of the last areas of Europe to convert to Christianity, there are numerous episodes in the sagas where the forces of Christendom must face heiðni (paganism, heathenry). Indeed, the struggles of missionary kings such as Óláfr Tryggvason (c. 960-1000) or Saint Óláfr (995-1030) against their pagan compatriots constitute the largest genre of encounters between Christians and nonbelievers in Old Norse literature. ${ }^{3}$ Unsurprisingly, there is little to suggest that the Christian authors of the thirteenth century believed their heathen ancestors to have had substantial corporeal differences from themselves. Conversion-era narratives imply that the proponents of heathendom, while they may have held disagreeable or short-sighted views, were a part of Norwegian/Icelandic history to be negotiated and integrated rather than 'Othered.' Charismatic individuals such as Jarl Hákon are proponents of an inimical faith, but they are also compelling anti-heroes. The basic strategy here asserts, 'They, the pagans, were us. They did not yet think like us, but they did still look like us. Their bodies were our bodies.' 
Another common religious enemy encountered in the sagas are the forces of Islam, variously represented by Serkir ('saracens'), blámenn (lit. 'dark men,' 'Africans'), or Tyrkjur ('Turks') (though it should be noted that none of these designates Muslims exclusively - for example, the pre-Islamic Persians of Alexanders saga are also Serkir). Here, we can see a more varied approach to the body as a site of difference. In some sagas, Muslims resemble pagans. Mirmanns saga (Anonymous, 1997) is a particularly arresting example of this trend. The story unfolds in a bizarre alternate reality, where Islam is the dominant religion of Europe (and where King Clovis was originally a Jew before discovering Christianity). While it is made very clear that the Muslims worship a god named 'Mahomet,' they are still described as heiðinn - the same term used to describe Scandinavian pre-Christians. There is no one Old Norse word corresponding to 'Muslim' as a purely religious appellation.

Like heathens, Muslims are often defended by proud and likeable (if fundamentally misguided) individuals. In Karlamagnus saga ok kappa hans, the warrior Agulandus gives a stirring oration in defence of his faith: 'It will never happen to me, that I will allow myself to be baptised and so deny that Mahommed is almighty. Rather, I and my people will fight against you and your men' ('Pat skal mik aldri henda, at ek láti skírast ok neita svá Maumet vera almátkan; heldr skal ek ok mitt fólk berjast viðr pik ok pina menn'; Anonymous, 1860, 146). More pointedly, when the triumphant Mírmann is standing over the dead body of the Muslim champion Lucidarius, he remarks: 'if you had been a Christian, you would have been a good knight' ('ef pv værer kristinn madur værer pv godur riddari'; Anonymous, 1997, 92-96). Here, the defenders of Islam do not seem to have acquired negative physical traits to express their negative beliefs. In fact, perhaps due to a perception of Muslims as a martial people, there is a tendency for them to be associated with vitality and vigour. The scant description of Agulandus's appearance mentions only that he is 'big and strong' ('mikill ok sterkr'; Anonymous, 1860, 133). Of Lucidarius it is said that 'he is a heathen, and hardy in battle' ('hann er heidinn og hardur i bardogumm'; Anonymous, 1997, 71), which implies a similar stature. The trope of the hearty and hale Muslim can also be found outside descriptions of champions. A Norse Marian miracle, which misremembers the Parthian Empire as an Islamic polity, begins with the words: 'In that country, which once was called Parthia but now is called Turkey, there were eighteen kingdoms. Those kingdoms were ruled by strong men, and it is said that since then there have often been strong and excellent men over there' ('A $p u i$ landi, er fyrr meir uar kallat Partia enn nu er kallat Tyrkland, uoru par atian riki. Fyrir peim rikium redu strykuir menn, ok pat er sagt, at par hafi sidann opt uerit styrkuir menn ok agcetir'; Anonymous, 1871, 990). There is a striking resonance here with the Turcophilia of Snorra Edda's prologue: 'just as the earth there is more beautiful and better in every way than in other places, so was the populace there most gifted with every gift, knowledge and strength, beauty and every kind of knowledge' ('svá sem par er jorðin fegri ok betri at ollum kostum en í oðrum 
4 The image of blámenn making disturbing noises to encourage each other as they go into battle is also found in Heimskringla (Snorri, 1951, 244). stoðum, svá var ok mannfólkit par mest tígnat af ollum giptum, spekinni ok aflinu, fegrðinni ok alls kostar kunnustu'; Snorri, 1988, 4).

The most extreme corporeal configuration of a Muslim in Old Norse literature must surely be that of the blámaðr. The blámaðr was one of the most versatile Others available to a medieval Scandinavian author, appearing not only as a Muslim but also as an inhuman demon in religious visions, a wild berserkr, or a Finnic savage in the far north. Blámenn, distinguished from Serkir, appear as the adversaries of Scandinavian crusaders in the historical works Orkneyinga saga (Anonymous, 1965, 225) and Heimskringla (Snorri, 1951, 244), but there is no information given on their physicality besides the skin tone implied in their name. For a more detailed account, we can turn to the imaginative Sörla saga sterka (Anonymous, 1889). Having set out from Norway, Prince Sörli and his men sail for days before landing in Africa:

At that moment they saw twelve men heading towards them, large, determined and unlike other human beings [mennskir men]. They were black and had ugly faces, with no hair upon their heads. Their brows [brýrnar] went all the way down to their noses. Their eyes were yellow like a cat's, and their teeth were like cold iron ... And when they saw the prince and his men they all began to squeal [at hrina] most fiercely, and egg [eggjandi] each other on ... then the blámenn descended on him with great excitement [eggja] and savage noises and bellowing.

(Anonymous, 1889,313$)^{4}$

If Agulandus and Lucidarius exemplify a noble Islam through their heroic, knightly bodies, the blamenn convey an altogether different impression. The author frequently enters the semantic field of the bestial: as Lindow observes, he defines the Muslims in opposition to 'human beings' (mennskir menn) (Lindow, 1995). They have feline eyes. Furthermore, the verb at hrina carries with it the connotations of 'to squeal like swine ... of an animal in heat' (Cleasby and Vigfússon, 1874, 286). These are half-animal bodies, but to what extent are they even half-human bodies? The brow that descends to the nose may be a racial caricature based on the supposed physiognomy of a sub-Saharan face, but it distorts the face to the point where it can scarcely be called human at all. The words brýrnar, eggjandi, and eggjan seem to pun on at brýna ('to sharpen') and egg ('edge,' particularly of a sword or spear). This, together with the teeth 'like cold iron' (sem kállt járn), suggest a countenance which is part animal, part ogre, part weapon.

These examples demonstrate that Old Norse authors did view the body as an appropriate site for articulating difference, whether cultural, racial, religious or somewhere in between. In the case of the Jews, however, the discourse is not so much one of appearance (that is, the difference in skin color, facial phenotypes, age and so on of a particular body). Rather, it is concerned with form. The 
difference lies in the organization of bodies, of how they operate together, not so much their mode of appearance as their mode of existence. The gyðingr can only be understood fully when its (eu)social relations are incorporated into a bodily assemblage: a body that is an assemblage of bodies. Aping Wittgenstein (Wittgenstein, 1968, \$19), 'to imagine a body is to imagine a form of life.' The Christmas day sermon from The Icelandic Homily Book, for example, presents a synthesis of Passion accounts from the Gospels. The Jews repeatedly clamour for Christ's blood, speaking and seemingly thinking as one. Here is just one instance of this dialogic form:

What more do we need to know? Now we can hear the blasphemy from His own mouth! What do you think?' Then they all call out and say: 'He deserves death!' Then some began to spit in His face, and they bound a cloth around His face, and throttled him, and laughed and said 'prophesy now, Christ, and tell everyone how you'll be saved.' And when they had laughed at him, and said many blasphemies to him, they delivered him to Pontius Pilate. But Pilate asked them: 'What do you have against this man?' The Jews replied. 'We would not deliver him, if he had not committed evil.' Pilate asked what evil he had committed. And they replied: 'He has gone astray from our nation, and refuses to pay the Emperor our taxes, and says himself to be a King.' Pilate said: 'You take him, and sentence him according to your laws.' (Anonymous, 1872, 172)

The Pharisees, themselves speaking in unison, address the other Jews using the plural pronoun, who in turn reply with eerie coordination. The plural Jews refer to the singular Pilate with the plural pér out of deference, and Pilate addresses them with the related form ér because they are many, but paradoxically the conversation reads more like one between two individuals. Indeed, the homilist himself seems to get rather confused by this dynamic when he mistranslates John 19.15: 'But they called out "Away with him! Away with him and crucify him!" Pilate said "shall I crucify your king?" A bishop [sic] replied (pl.) "We have no king but caesar"' ('En peír collopo. Tolle tolle crvcifige eum. Pilatus molte. Scal ec crosfesta regem vestrum. Episcopus svoropo. Enge hofom vér conung nema keisera'; Anonymous, 1872, 172). The concept of the Jews communicating as a chorus does not originate in Old Norse literature. There is a precedent in the Old Testament from Exodus 24.3: 'And Moses came and told the people all the words of the Lord, and all the judgements: and the people answered with one voice, and said, "All the words which the Lord hath said will we do.",

Similarly, the curious framing of the dialog between Pilate and the Jews derives from the rhetoric of Matthew. But what impression must this homily have left with an uneducated audience, unable to read the Bible in their own language and unaware of such biblical intricacies? An Old Norse-speaking congregation can 
surely be afforded the curiosity to wonder what sort of people these gyðingar are, who possess unanimous will and speech. There was no Jewish settlement in Scandinavia during the Middle Ages (Gad, 1963, 73), and no evidence of Jewish visitors after Ibrahim ibn Ya'qub in 965, so there were no lived experiences to inform the mind's eye as audiences struggled to visualize the scenes being described to them. Hearing these striking but baffling words from the priest's mouth, and then looking upward and seeing a piece of church art such as the one from Åhus reproduced at the beginning of this essay, it would be entirely reasonable for them to assume that this was not just an odd rhetorical device. Rather, they would have thought: this is the nature of the Jews. Old Norse speakers knew that paganism and Islam had the capacity to articulate their enmity through individual actors such as Agulandus or Jarl Hákon. The Jews (not 'the Jew') were a different entity entirely.

The theme of the massed body continues along the liturgical calendar with the sermon that would have been heard immediately following the Christmas homily - that is, on the feast day of St. Stephen the proto-Martyr. Again, the Jews act cohesively with all the expected tropes - for example: 'The Jews frowned at him and gnashed their teeth, filling with evil as they heard his rebuke' ('Gypingar ygldosc a hann. oc gnísto tonom. fylldosc illzco es peir heýrpo avit hans'; Anonymous, 1872, 175). But in St. Stephen's homily, it is also demonstrated that the contiguous assemblage of the Jews can be cleaved, and that Christianity has the power to pull a piece from the massed body, disconnecting it from the Jewish collective consciousness in the process. Here, St. Stephen makes his final prayer, and Saul of Tarsus is dramatically reborn as St. Paul:

Then he fell to his knees and called out in a loud voice saying: 'Lord, do not punish them for this sin.' Think, good brothers, how much love Stephen had. While he stood, he prayed for himself, but when he fell to his knees he prayed for his enemies ... And this prayer which Stephen said for his enemies was heard by God, because Saulus, who is one of the leaders of all those who stoned Stephen, was turned to God by Stephen's prayer and made an apostle and a teacher of nations ... He who lies down with Paul is evil, he who stands up with him is good, because he fell down evil and he stood up good. He fell down a vicious, stiff-necked man, but he rose up wonderfully aware. And now he is connected to Stephen in the glory of heaven, for he was made a sheep out of a wolf.

(Anonymous, 1872, 178)

St. Stephen's dying prayer is colored not so much as a forlorn resignation, but more like a war cry - the 'loud voice' of 'a knight ... of Christ ... that would transcend the beastliness of the Jews' ('mikille roddo ... crist $[s]$... ripera ... at hann mętte stíga yfer grimleíc Gypinga'). That prayer, 'Drótten gialldpu eige peím synp pessa' - 'Lord, do not punish them for this sin' (but don't forgive them either!) - becomes an act of retaliation, whereby Saulus is struck physically, 
falling to his knees, by the force of ást ('love'). Saulus of Tarsus is disaggregated, and comes to his senses, now connected (samtengðr) to the assemblage of Christendom. Deleuze and Guattari's thinking becomes relevant again here. Saulus was a wolf (vargr), existing only among many wolves. But St. Stephen's power makes him divisible, tangible, countable. He makes a man from the mass, reconfiguring the social relations governing his body so that it may be defined as individual. The homilist explains that this force of love works as follows: 'Paul was not ashamed of Stephen's death. Rather, Stephen rejoices in Paul's fellowship, because love receives them both. Stephen's love transcended the beastliness of the Jews but Paul's love repents for a multitude of sins. ${ }^{5}$ Love is the bride and the origin of all good things and an excellent life' (Anonymous, 1872, 178). One wonders too, if Deleuze and Guattari's definition does not also apply here: 'What does it mean to love somebody? It is always to seize that person in a mass, extract him or her from a group, however small, in which he or she participates' (Deleuze and Guattari, 2004, 39).

The Jews first entered the stage of Old Norse literature in homiletic material, but it is arguably in the Marian miracles of the thirteenth to fourteenth centuries where the antisemitic imagination impels them to put on their most dramatic performances. This was the period where the Marian cult in Iceland was in its ascendancy, and as Rubin has shown, where the cult of the Virgin trod, hostile sentiments toward Jews tended to follow (Rubin, 2010, 228-242). Although the vast majority of Norse miracula are close adaptations or translations from continental models, those that feature Jews often appear to have been chosen so as to provide continuity with the image of the massed body inherited from the homilies. A number of instances could be cited here, but for the sake of brevity the focus will be on one example: the Norse version of the Toledo miracle (Widding, 1996, 117).

It is said that in Toledo, which Scandinavians call Tolhus (this town is in Spain and a third of the town's population are Christians, the second third Jews, the third heathens [i.e., Muslims]) ... a voice was heard in the sky ... which thus spoke with a piteous tone: 'Ha! Ha! An affliction, what an affliction, that Jews with such cunning and evil should live so near to God's flock [B: earth] and these sheep which are marked with the protecting symbol of the Holy Cross, because now the Jews wish to scorn and mock and crucify my son for a second time.' This prompted much fear and concern amongst the Christians. And after the mass the Archbishop consulted with the common people what course should be taken, and everyone agreed to go to the houses and shacks of the Jews and search them as carefully as possible for whatever might be going on. First they went to the hall which the rabbi [byskup gyðinga] owned and searched there. And when the archbishop came to their synagogue there was found a statue made of wax, in the likeness of a living man. It was battered and spit-drenched, and there were many people of the Jewish race falling on
5 Potentially a dual meaning. Less likely but still plausible: 'sins of the multitude.' 
their knees before the statue, some slapped it on the cheek. Also, there stood a cross nearby, and the Jews had intended to nail that statue to the cross for the mockery and insult of Our Lord Jesus Christ and all who believed in Him. And when the Christians saw this, then they destroyed that statue and killed all the Jews who were present.

(Anonymous, 1871, 110-111; cf. 722-724)

To an audience in the Judenfrei space of medieval Iceland, this tale of the horrors of multicultural Spain must have had compelling power. But it is not the Islamic third of the town that is the enemy. Rather, it is the Jews, up to the same tricks and possessing the same physicality known from Norse adaptations of the Gospels. Like the baying crowds of Matthew, the gyðingar here seem to require no leader or spokesman. When living among Christians, they may present the appearance of having a leader in their rabbi, but ultimately this is only a front - a single actor's mask that thinly conceals a whole chorus. After all, the rabbi's house is empty. The conspiracy has not been orchestrated by a leader and so it does not occur in the leader's space. Rather, the conspiracy takes place in the communal space of the synagogue. It is an act of collective will. The hive-mind acts instinctively as one, each Jew equally a party to the conspiracy as any other. The ritual re-enactment of the crucifixion (and we must assume it is supposed to be a ritual, as they are clearly not doing this for the benefit of a Christian audience) does not require any particular coordination. In a manner reminiscent of eusocial creatures, they exhibit an instinctive division of labour: some mockingly worship, others slap the statue. In time, it will be nailed to the cross. All this happens without any hint that the rabbi is needed to officiate or assign roles.

Note here also that an alternate manuscript substitutes iörðu ('earth') for biörðu ('herd'). A slip of a scribe's pen perhaps, but it is interesting that this is the word that is changed. Naturally, the metonymy of the massed Jews as 'wolves' versus Christians as 'sheep' has plenty of biblical precedents, for example, Matthew 7.15, 10.16, Luke 10.3, John 10.12, Acts 20.26-30. It is repeated a few times in Old Norse. Another miracle is set in 'a certain populous town where there lived both Christians and Jews, but their homes were divided like sheep from wolves' ('nockvrri fiolmennri borg voro bøði samt kristnir menn ok gyðingar, po greindir i herbergium sem swðir fra vørgvm'; Anonymous, 1871, 203-206). Later, an agent of that same Jewry is described as 'a noxious wolf in sheep's clothing' ('skøðr vargr vndir swðar asionv'), and the story is summarized as 'Jews have craftily mocked God's flock' ('gyðingar hafa prettvissliga gabbat swðaher guð'). We have already seen another example from the homily of St. Stephen. In any other literature, this would be an uncomplicated (if unpleasant) polemical strategy. However, in Old Norse, where the massed body stresses the aberrant, threatening qualities of aggregated sameness, it becomes newly problematic. There is a fundamental contradiction: if the Jews all think, feel and act 
as one, and that is an undesirable trait, why are the Christians being called sheep? If the 'flock'/'earth' variation is nothing more than a random scribal error, it is an extremely convenient one.

In concluding, we might observe two different implications for this way of thinking for two different contexts. First, there is the usefulness of the perception of Jews as a massed body (that is, a corporate entity) for a medieval Icelander. Second, there is the implication of such thinking for the broader question to which this special issue of postmedieval is dedicated - namely, how can the Middle Ages engage in a dialog with Holocaust studies? To begin with the Norse context, I would contend that ultimately it is the question of oneness that the Jews pose to medieval Icelandic society that makes them an enemy in a way that pagans or Muslims cannot be. Jews in Old Norse literature defend a common interest, formulate common plans and work as a single unit to put them into practice. This is something the Icelanders, as a community, failed to do. From 930, when the Alpingi was founded at Pingvellir, they pioneered an extraordinary system of governance. There were law codes and judges, but no executive power. As Shippey puts it, summarizing Byock (1988): 'it was a country that ought to have been a Utopia. It had: no foreign policy, no defence forces, no king, no lords, no peasants, no dispossessed aborigines, no battles (till late on), no dangerous animals, and no very clear taxes. What, given this blank slate, could possibly go wrong? Why is their literature all about killing each other?' (Shippey, 1989, 16-17) Although the so-called 'Free State' has had its scholarly defenders, it is impossible to deny that in the end, the law was not an organ to realize a collectively agreed vision of society, but an instrument of personal retribution. When the Jews of The Icelandic Homily Book, following John 19.7, scream out 'We have a law and by that law He must die' (Anonymous, 1872, 172), they demonstrate a unanimity of spirit which would have been unthinkable to a medieval Icelander. Describing the deep-seated ideology of individualism which dominated Icelandic thought, Foote notes that 'they [were] not confused by loyalties other than those naturally imposed by kinship, friendship and the free contract they freely make [it was] a past ideally simplified by a reduction to individual, all human, existential terms' (Foot, 1984, 55). Even after 1262, when the Icelanders were unified into the kingdom of Norway and so were exposed to institutions which were supposedly expressions of social will, the apparent singularity of Jewish consciousness must have remained a sore reminder of their own failure. The Jews literally embody the principle of cooperation that the Icelanders never achieved for themselves.

The ways in which the Norse notion of the massed body might pertain to an interrogation of the Shoah are more problematic, and here we may have to content ourselves with further questions rather than offering firm answers. How far can we assert that the Norse-speaking enthusiasm for tales of violence and extinction against distant Jewish communities parallels the experience of many gentile Europeans during the Holocaust? After all, Nazism, with its attendant 
narrative of a malignant Jewish conspiracy poisoning all of Europe, found supporters even in countries that only had very small and inconspicuous Jewish populations - for example, Norway, Finland or Estonia (incidentally, a country where the 'Final Solution' was fully executed; not a single Estonian Jew remained after 1941). Moreover, the existence of Old Norse versions of continental antisemitic lore hints that the fantasy of eliminating Jewish presence in Europe was much deeper - and much more widespread - than the established medievalist focus on more mainstream European literatures suggests. Even on the frozen periphery of the continent, people were digesting tales of Jewish cabals, revelling in the righteousness of violent retaliations, and engineering sophisticated corporeal strategies to rationalize this distant yet imminent threat. A consideration of antisemitism in medieval Scandinavia might therefore lend credence to the rather lachrymose proposition that the thought of the Middle Ages is a distant but nonetheless direct ancestor of the psychology that inspired the perpetrators of the Holocaust. Attendant to this narrative is the prospect of historical inevitability. The mass extermination of Jews (that is, the Holocaust), like human flight or space travel, was something that certain Europeans had been meditating upon in various forms for hundreds of years before they acquired the technology and clarity of purpose to make it happen. Naturally, the Old Norse component in this dismal intellectual tradition is minuscule, but it does attest the longevity and pervasiveness of a dangerous mental fixture: 'The Jews,' plotting as one, acting as one, eventually to be eliminated as one.

\section{About the Author}

Richard Cole is a Visiting Fellow at Harvard University. His PhD thesis, begun at University College London and since transferred to Harvard University, examines perceptions of Jews in Old Norse literature, against the backdrop of an apparent absence of Jewish settlement in medieval Iceland and Norway. He has taught Old Norse at UCL and Århus Universitet, Denmark (E-mail: richardcole@fas.harvard.edu).

\section{References}

Andersson, T. trans. 2003. Introduction. In The Saga of Olaf Tryggvason, by Oddr Snorrason. Ithaca, NY: Cornell University Press.

Anonymous. 1860. Karlamagnus saga ok happa hans, ed. C.R. Unger. Christiania, Denmark: H.J. Jensen.

Anonymous. 1871. Mariu Saga. Legender om Jomfru Maria og hendes jertegn, efter gamle haandskrifter, ed. C.R. Unger. Christiania, Denmark: Brögger \& Christie.

Anonymous. 1872. Homiliu-Bók. Isländska Homilier efter en Handskrift från Tolfte Århundradet, ed. T. Wisén. Lund, Sweden: C.W.K. Gleerups Förlag. 
Anonymous. 1889. Fornaldarsögur Norðrlanda. Vol. 3 ed. V. Ásmundarson. Reykjavík, Iceland: Sigurður Kristjánsson.

Anonymous. 1965. Orkneyinga saga, ed. F. Guðmundsson. Reykjavík, Iceland: Hið Íslenzka Fornritafélag.

Anonymous. 1997. Mírmanns saga, ed. D. Slay. Copenhagen, Denmark: C.R. Reitzels Förlag.

Björnsson, B.T. 1954. Íslenzka teiknibókin i Árnasafni. Reykjavík, Iceland: Heimskringla.

Byock, J. 1988. Medieval Iceland: Society, Sagas and Power. Berkeley, CA: University of California Press.

Cleasby, R. and G. Vigfússon. 1874. An Icelandic-English Dictionary. Oxford, UK: Clarendon Press.

Cohen, J. 1999. Living Letters of the Law: Ideas of the Jew in Medieval Christianity. Berkeley, CA: University of California Press.

Degnbol, H. et al. 1989. Ordbog over det norrøne prosasprog. Copenhagen, Denmark: Den Arnamagnæanske Samling.

Deleuze, G. and F. Guattari. 2004. A Thousand Plateaus: Capitalism and Schizophrenia. trans. B. Massumi. London: Continuum.

Foote, P. 1984. The Audience and Vogue of the Sagas of Icelanders - Some Talking Points. In Aurvandilstá, ed. M. Barnes, et al, 7-55. Odense, Denmark: Odense University Press.

Gad, T. 1963. Jøder. In Kulturhistorisk Leksikon for Nordisk Middelalder, ed. A. Bugge, et al, Vol. 8. Copenhagen, Denmark: Rosenkilde \& Bagger.

Kirby, I. 1986. Bible Translation in Old Norse. Geneva, Switzerland: Librairie Droz.

Kruger, S. 1992. The Bodies of Jews in the Late Middle Ages. In The Idea of Medieval Literature: New Essays on Chaucer and Medieval Culture in Honor of Donald R. Howard, eds. J.M. Dean, and C.K. Zacher, 301-323. London: Associated University Press.

Kruger, S. 2005. The Spectral Jew: Conversion and Embodiment in Medieval Europe. Minneapolis, MN: University of Minnesota Press.

Krummel, M. 2011. Crafting Jewishness in Medieval England: Legally Absent, Virtually Present. New York: Palgrave Macmillan.

Lindow, J. 1995. Supernatural Others and Ethnic Others: A Millennium of World View. Scandinavian Studies 67(1): 8-31.

Rubin, M. 1999. Gentile Tales: The Narrative Assault on Late Medieval Jews. Philadelphia, PA: University of Pennsylvania Press.

Rubin, M. 2010. Mother of God: A History of the Virgin Mary. London: Penguin Books.

Shippey, T. 1989. Review of Jesse Byock's Medieval Iceland. The London Review of Books 11(11): 16-17.

Snorri Sturluson. 1945. Heimskringla. Vol. 2, ed. B. Aðalbjarnarson. Reykjavík, Iceland: Hið Íslenzka Fornritafélag.

Snorri Sturluson. 1951. Heimskringla. Vol. 3, ed. B. Aðalbjarnarson. Reykjavík, Iceland: Hið Íslenzka Fornritafélag.

Snorri Sturluson. 1988. Edda. Prologue and Gylfaginning, ed. A. Faulkes. London: Viking Society for Northern Research.

Straubhaar, S. 2001. Nasty, Brutish and Large: Cultural Difference and Otherness in the Figuration of the Trollwomen of the Fornaldar sögur. Scandinavian Studies 73(2): 105-124.

Tomasch, S. 2000. Postcolonial Chaucer and the Virtual Jew. In The Postcolonial Middle Ages, ed. J.J. Cohen, 243-260. New York: St. Martin’s Press. 
Trachtenburg, J. 1943. The Devil and the Jews. The Medieval Conception of the Jew and its Relation to Modern Anti-Semitism. New York: Harper \& Row.

Widding, O. 1996. Norrøne Marialegender på europæisk baggrund. Opuscula 10: 1-128.

Wolf, K. 1990. Brandr Jónsson and Stjórn. Scandinavian Studies 62(2): 163-188.

Wittgenstein, L. 1968. Philosophical Investigations, trans. G.E.M. Anscombe, $\mathbb{1 9}$, Oxford, UK: Blackwell. 